\title{
A REPRODUKCIÓS ÖREGEDÉS ÉS A CSONTSZERKEZET VÁLTOZÁSÁNAK KAPCSOLATA NÖKNÉL
}

\author{
Zsákai Annamária és Bodzsár Éva \\ Eötvös Loránd Tudományegyetem, Embertani Tanszék, Budapest
}

\begin{abstract}
Zsákai A., Bodzsár É.: The relationship between reproductive ageing and the changes of bone structure in women. The main purpose of the study was to analyse the relationship between menopausal status and the bone structure in women. A random sample of 1932 Hungarian women (aged 25-95 years) was to be enrolled in the study between 2012 and 2015. Bone mass was estimated by the Drinkwater-Ross anthropometric four-component method. Bone structure parameters were assessed by a quantitative ultrasound DTU-one device. Subjects were divided into menopausal subgroups on the basis of their menstrual history. The risk of osteoporosis was identified by using the thresholds of ultrasound parameters recommended for the DTU-one device. The ultrasound parameters' reference values were constructed in the studied age-group of Hungarian women for the DTU-one sonometer. An intensive, menopause-related change from the late 40s and a significant change from the beginning of the $70 \mathrm{~s}$ were observed in the bone structure of women. The 15-17\% of women were at very high risk for osteoporosis in the premenopausal status subgroup. After the menopausal transition the decreased level of female sex hormone production doubled this risk of osteoporosis for the beginning of the postreproductive period, and triplicated this risk in the 70s of women. Premature menopause was found to be accompanied by the increased risk of osteoporosis during the whole studied age interval.
\end{abstract}

Keywords: Menopause; Bone mass; Bone structure; Osteoporosis; Quantitative ultrasound method.

\section{Bevezetés}

Az időskori oszteoporózis gyakorisága napjainkban világszerte fokozódik, átlagosan minden harmadik nö és minden ötödik férfi esetében következik be oszteoporotikus eredetű törés a 60 évestől idősebbek korcsoportjában. A csontszerkezet ezen betegségét az élettani és biomechanikai folyamatok öregedést kísérő változásaiból, a fokozott csontvesztésből adódó teljes és egységnyi térfogatra jutó csökkent csonttömeg jellemzi, amely csontszerkezeti jellemzők együttesen a csonttörések kockázatát növelik (Cummings és Melton 2002, Johnell és Kanis 2006, Hernlund és mtsai 2013, Svedbom és mtsai 2013, Weaver és mtsai 2016). A gazdaságilag fejlett társadalmak öregedő korstruktúrája és az egyre nagyobb gyakoriságú időskori oszteoporózis népegészségügyi következményei együttesen a betegség epidemiológiai szürőprogramjainak fontosságát hangsúlyozzák.

$\mathrm{Az}$ oszteoporózis diagnózisa csontsürüségi illetve a csontszerkezet minőségi vizsgálatai segítségével állítható fel. A diagnosztikai csontsűrüségi vizsgálatok egyelőre még mind nagymüszeres képalkotó technikákra épülnek (pl.: DEXA), míg a csontszerkezeti vizsgálatok egyelőre leginkább a csonttörékenységi gyakoriságra vonatkozó anamnézist mérik fel. A csontszerkezet ultrahangos vizsgálatait egyelöre még csak a szürővizsgálatokban használják, diagnosztikai jelentőségük minimális. Pedig az ún. mennyiségi ultrahangos vizsgálatok (quantitative ultrasound, QUS) diagnosztikai 
érzékenysége igazoltan a DEXA abszorptiometriás technika érzékenységével azonos nagyságrendü, nem jelent potenciális veszélyforrást, hiszen az ultrahang a nagymüszeres képalkotó technikákkal szemben nem jelent sugárveszélyt, az emberi test perifériás területein lévő csontok vizsgálatára épül, alkalmazása minimális anyagi költséggel jár. Éppen ezért tartják a QUS módszert, ami a csontszerkezet vizsgálatán túl a csontsürüségre is elfogadhatóan pontos becsléssel szolgál, napjainkban a foton-abszorptiometriára épülő eljárás egyik lehetséges alternatívájának, és ajánlják az oszteoporózis diagnosztikájában is alkalmazását (Njeh és mtsai 1997, Truscott 1997, Roux és mtsai 2001).

A foton-abszorptiometriás csontsürüségi vizsgálatokban a WHO Collaborating Centre for Metabolic Bone Diseases szakértői csoportja $\mathrm{T}$ érték $\leq-2,5$ kritikus értéket javasolta (T érték: egészséges, 30 éves felnőttek esetében optimális csontsürüség értékétöl való eltérés szórás egységben kifejezve) az oszteoporózis diagnózisának megállapításához (Kanis és mtsai 1994, WHO 1994). A DEXA és ultrahangos vizsgálatok együttes használata azonban igazolta, hogy ez a típusú határérték a QUS vizsgálatokban nem alkalmazható a betegség megállapítására (Roux és mtsai 2001). Éppen ezért Clowes és munkatársai (2006) a különböző típusú QUS ultrahangos müszerekre külön-külön meghatározták az ultrahangos csontszerkezeti paraméterek oszteoporózist jelző kritikus határértékeit DEXA müszer alapján oszteoporózissal diagnosztizált és egészséges csontszerkezetű emberek DEXA és QUS müszerekkel elvégzett együttes vizsgálatainak eredményei alapján.

A 40-es éveik végétől a nők fokozottabban vannak az oszteoporózis kialakulása veszélyének kitéve, mint a fiatalabb korú nök vagy férfi kortársaik, hiszen körükben a menopauzális átmenetet kísérő női nemi hormonok termelődésének csökkenése, az anyagcsere mutatóinak változása és az életkor elörehaladtával járó csökkent mértékü fizikai aktivitás együttesen a testszerkezet és ezen belül a csontszerkezet jelentős mértékü változását indítja el (WHO 2003, Lane 2006, Compston és mtsai 2014, Cosman és mtsai 2014).

Mindezek alapján vizsgálatunk fö célkitüzése volt, hogy elemezzük a nők csontszerkezeti változásait, illetve az oszteoporózis kockázatának változását a menopauzális átmenet során a nők QUS csontszerkezeti mutatói alapján.

\section{Vizsgált személyek és alkalmazott módszerek}

Vizsgált személyek

A test- és csontszerkezeti vizsgálatba bevont nők (25-95 évesek, n: 1932 fö, 1. táblázat) reprodukciós és menstruációs történetére, valamint általános egészségi állapotára vonatkozóan a személyes interjúkon kérdőívek segítségével gyüjtöttünk adatot a 2011 és 2014 között végzett keresztmetszeti vizsgálat során. A vizsgált nőket tízéves korcsoportokba, illetve menstruációs történetük alapján menopauzális státusz alcsoportokba soroltuk be (Zsákai és mtsai 2015, 2016). A korai menopauzát a 45 éves kor elött bekövetkezett menopauza esetében állapítottuk meg. A testösszetételt és csontszerkezetet jelentősen befolyásoló betegségekben szenvedő nők, illetve a méh és/vagy petefészek eltávolításán átesett nők adatait a jelen elemzésből kizártuk.

\section{Alkalmazott módszerek}

A nők abszolút csonttömegét a Drinwater-Ross - féle (1980) négykomponensü antropometriai módszerrel becsültük. A csontszerkezet mutatóit (ultrahang sebessége, 
speed of sound, SOS, m/s; frekvenciafüggö ultrahang-gyengülés, broadband ultrasound attenuation, BUA, dB/MHz) egy DTU-one típusú (Osteometer Meditech, California, USA) ultrahangos müszerrel becsültük a bal láb sarokcsontján.

Az oszteoporózis kockázatának mértékét (nincs kockázat: mindkét mutató értéke egyelő vagy nagyobb, mint a kritikus érték; magas kockázat: a két csontszerkezeti mutató egyike kisebb, mint a kritikus érték; nagyon magas a kockázat: mindkét mutató értéke kisebb, mint a kritikus értékek) a DTU-one müszer csontszerkezeti paramétereire Clowes és munkatársai (2006) által meghatározott kritikus határértékek (BUA $\leq 35,1 \mathrm{~dB} / \mathrm{MHz}$, $\mathrm{SOS} \leq 1528 \mathrm{~m} / \mathrm{s}$ ) figyelembe vételével becsültük.

A statisztikai elemzéseket az SPSS v. 23 programcsomaggal végeztük. Hipotéziseinket 5\%-os szignifikancia-szinten teszteltük. A csontszerkezeti mutatók centilis-mintázatát az LMS módszerre épülő lmsChartMaker Pro 2.3 programmal határoztuk meg (Medical Research Council, UK 1997-2006; Cole and Green 1992, Cole and Pan 2004).

1. táblázat. A vizsgált személyek életkori megoszlása.

Table 1 . The distribution of subjects by age-groups.

\begin{tabular}{lcc}
\hline $\begin{array}{l}\text { Életkor (év) } \\
\text { Age (years) }\end{array}$ & $\mathrm{n}$ & $\%$ \\
\hline 25,1-35,0 (Korcsoport/Age-group 30) & 185 & 9,6 \\
35,1-45,0 (Korcsoport/Age-group 40) & 192 & 9,9 \\
45,1-55,0 (Korcsoport/Age-group 50) & 256 & 13,3 \\
55,1-65,0 (Korcsoport/Age-group 60) & 357 & 18,5 \\
65,1-75,0 (Korcsoport/Age-group 70) & 275 & 14,2 \\
75,1-85,0 (Korcsoport/Age-group 80) & 347 & 18,0 \\
85,1-95,0 (Korcsoport/Age-group 90) & 320 & 16,6 \\
Együtt - Together & 1932 & 100,0 \\
\hline
\end{tabular}

\section{Vizsgálati eredmények és értékelésük}

A DTU-one oszteométer hazai referencia centilis-sorozatait a 25-90 éves nők korcsoportjára a vizsgált minta adatai alapján megszerkesztettük (1. ábra, 2. táblázat). Mindkét ultrahangos csontszerkezeti mutató esetében elmondható, hogy az életkor elörehaladtával jelentösen csökkent értékük a vizsgált mintában, a BUA mutató monoton csökkenése írható le a vizsgált teljes korintervallumban, míg a SOS csontszerkezeti mutató esetében a nők 45 éves korától egy intenzívebb csökkenő tendencia figyelhető meg (1. ábra). Mindezekkel ellentétben a csonttömeg a nők 60-65 éves koráig szinte változatlan értékủ volt, jelentős, életkorral előrehaladó csökkenését csak a 65 évestől idősebb nők körében tudtunk igazolni a vizsgált korintervallum végén. A reproduktív életkori szakaszukban lévő nők csontszerkezeti mutatói jelentősen jobbak (nagyobb értékủek) voltak, mint posztmenopauzális státuszú kortársaiknak. Ezzel szemben a nők menopauzális státusz alapján elkülönített alcsoportjainak abszolút csonttömege nem különbözött jelentősen (1. ábra). 

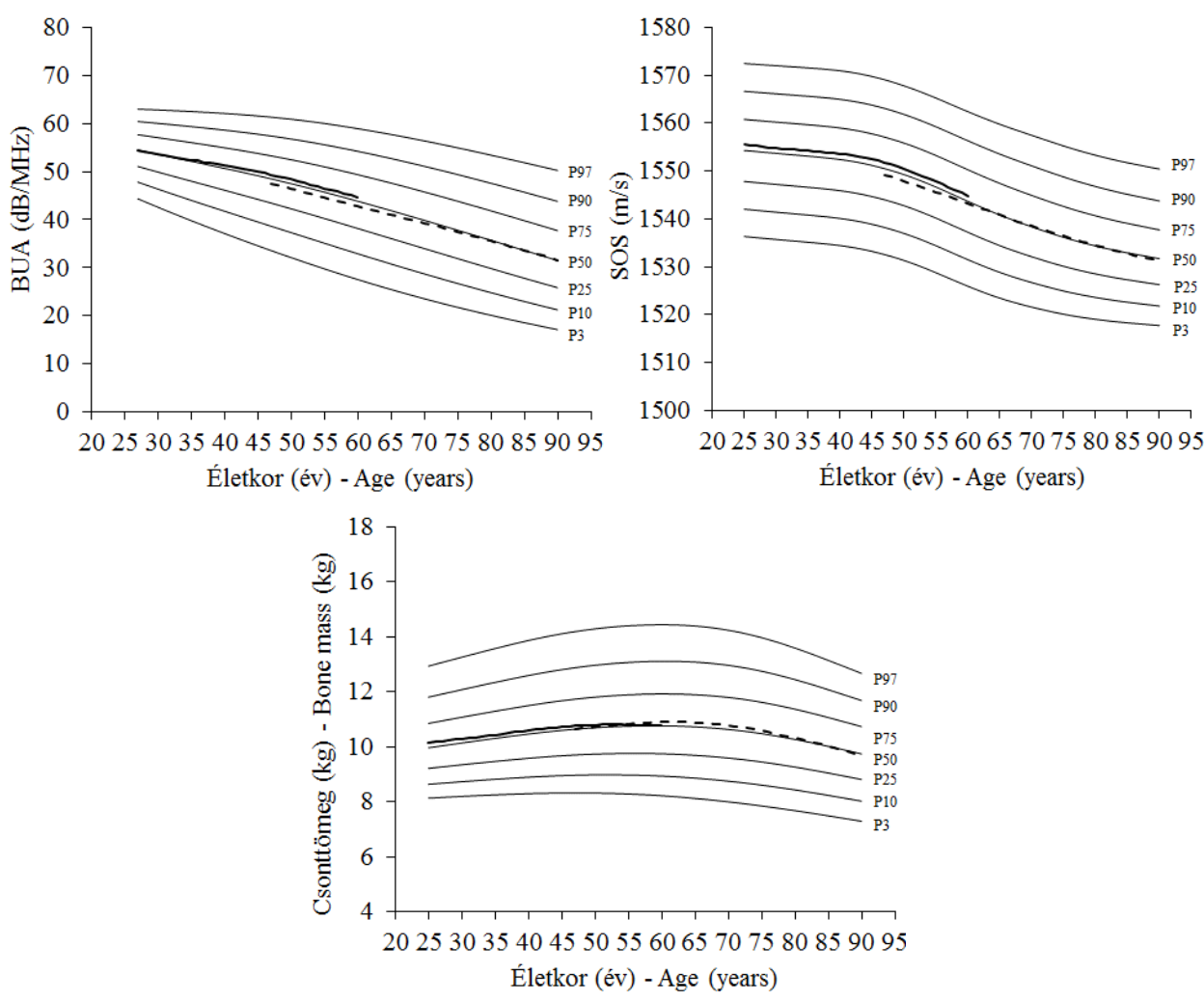

1. ábra: Az ultrahangos csontszerkezeti mutatók és az abszolút csonttömeg centilis-mintázatai 25-90 éves nőknél (premenopauzális státuszú nők: — és posztmenopauzális státuszú nők: - - -). Fig. 1: The centile distribution of quantitative ultrasound parameters and absolute bone mass in women aged between 25 and 90 years (median curves of premenopausal: - and postmenopausal:

$$
\text { - - - subgroups). }
$$

A posztmenopauzális státuszú nők alcsoportjában az oszteoporózis kockázata jelentősen nőtt az életkor elörehaladtával, különösen intenzíven nőtt a 70 évestől idősebbek körében (2. ábra): a betegség kialakulásának magas és nagyon magas kockázata az 50 évesek korcsoportjától kezdve a közel 20\%-os relatív gyakoriságról a 80 évesek korcsoportjáig 65\%-os gyakoriságra nőtt a posztreprodukciós életszakaszukba már belépett nők körében. Ezzel szemben a még reprodukciós életkori szakaszukban lévő nők körében a betegség kialakulásának kockázata nem változott az életkor előrehaladtával: az oszteoporózis magas kockázatát a premenopauzális státuszú nők esetében 1,5-2,5\%-ra becsülhetjük a vizsgált csontszerkezeti mutatók alapján, míg a betegség nagyon magas kockázatát a premenopauzális státuszú nők további közel 15\%-ánál írhatjuk le. Mindez azt mutatja, hogy a reproduktív életszakaszukban a nők átlagosan 15-17\%-a esetében magas az oszteoporózis kialakulásának kockázata, míg a menopauzális átmenetet kezdetén a nemi hormonok csökkent termelődési szintjének következtében a betegség kialakulásának kockázata megduplázódott a vizsgált mintában, és a 70 éves és attól idősebb nők körében már megháromszorozódott a betegség kockázata (2. ábra). 

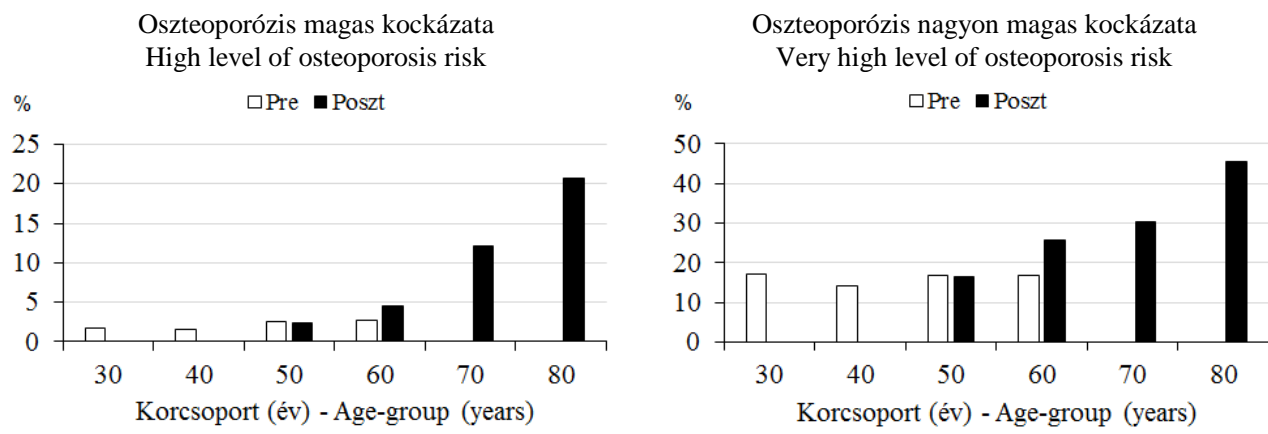

2. ábra: Az oszteoporózis magas ill. nagyon magas kockázatával beazonosított nők előfordulási gyakorisága (\%) a menopauzális státusz szerint kialakított alcsoportokban (Pre: premenopauzális, Poszt: posztmenopauzális státuszúak).

Fig. 2: Prevalence (\%) of women identified with high and very high level of osteoporosis by menopausal status (Pre: premenopausal, Poszt: postmenopausal status).

A korai menopauzát átélt nők ultrahangos csontszerkezeti mutatóinak eloszlási mintázata jelentősen eltért a mutatók vizsgált mintára jellemző általános centilismintázaitól (3. ábra): mindkét csontszerkezeti mutató, a BUA és a SOS mutató esetében igaz volt, hogy a korai menopauzával jellemezhető nők csontszerkezeti mutatói rosszabbak voltak, mint kortársaiknak végig a vizsgált életkori intervallumban.
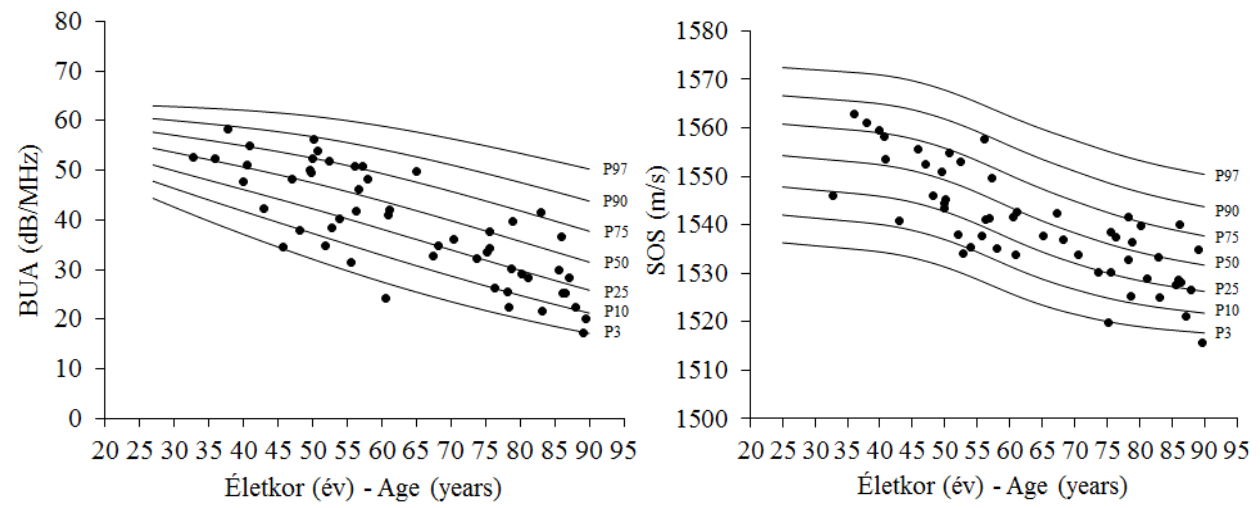

3. ábra: Korai menopauzát átélt (menopauzakor $\leq 45$ év) nők egyedi BUA és SOS ultrahangos csontszerkezeti mutatóinak $(\bullet)$ eloszlási mintázata a QUS mutatók vizsgált mintára jellemző centilis-mintázatán (BUA és SOS: $\mathrm{p}<0,05, \chi^{2}$ teszt).

Fig. 3: BUA and SOS quantitative ultrasound parameters of women $(\bullet)$ with premature menopause (age at menopause $\leq 45$ years) in the centile distribution of the studied population' QUS parameters (BUA and SOS: $p<0.05, \chi^{2}$ test).

\section{Következtetések}

$\mathrm{Az}$ időskori oszetoporózis diagnosztikájában még egyelöre nem, viszont szürővizsgálataiban az ultrahangos technikák egyre inkább elterjedtek napjainkban. Az International Quantitative Ultrasound Consensus Group szakértői csoportja az 
oszteoporózis ultrahangos szürővizsgálatait legalább a nők menopauzális átmeneti életszakaszában és az azt követő posztreprodukciós életszakaszában ajánlotta már az 1990-es évek második felétől (Gluer és mtsai 1997). A csoport ajánlásait követve célunk volt, hogy a nők menopauzális átmenetet kísérő csontszerkezeti változásait jellemezzük a DTU-one oszteométeres vizsgálataink során, ill. a célcsoport körében az oszteoporózis kialakulásának kockázatát felmérhessük.

Vizsgálati eredményeink alapján kijelenthetjük, hogy

(1) a nők menopauzális átmenetre jellemző női nemi hormonok szintjében megjelenő változások a csontok szerkezetének jelentős változásával társultak a vizsgált korintervallumban. Meglepő módon a csontszerkezeti változásokat nem kísérte a csontok tömegének jelentős változása. A női csontszerkezet reprodukciós öregedést kísérő változásainak pontosabb megismerése érdekében indítandó longitudinális vizsgálatunk eredményei reméljük hamarosan ezt a látszólagos ellentmondást feloldják majd.

(2) Az oszteoporózis kialakulásának kockázata a posztreproduktív életszakasz kezdetéig nem fokozódik a nők körében, átlagosan 15-17\%-os gyakoriságú volt a betegség kialakulása magas kockázatával jellemezhető premenopauzális nők gyakorisága, az átmenet idejében ez a gyakoriság nagyjából megkétszereződött, majd a nők 70 éves korcsoportjától ez a megnövekedett kockázat még tovább fokozódott.

(3) A korai menopauzát átélt nők csontszerkezeti mutatóit értékelve megállapítható volt, hogy a női reproduktív életszakaszra jellemző hormonális státusza nemcsak a reproduktív életszakasz végére, hanem a teljes posztreproduktív életszakaszra jellemző csontszerkezetet is meghatározza.

Köszönetnyilvánítás: A vizsgálat az Országos Tudományos Kutatási Alapprogramok támogatásával (OTKA K83966. számú pályázat) valósulhatott meg. A tanulmány a Bolyai János Kutatási Ösztöndíj támogatásával (ZsA, 2014-2017) készült.

\section{Irodalom}

Clowes, J.A. Peel, N., Eastell, R. (2006): Device-specific thresholds to diagnose osteoporosis at the proximal femur. Osteoporos International, 17: 1293-1302. DOI: 10.1007/s00198-006-0122-1

Cole, T., Pan, H. (2004): LMS program version 1.29. A program for calculating age-related reference centiles using the LMS method. Institute for Child Health, London.

Cole, T.J., Green, P.J. (1992): Smoothing reference centile curves: The LMS method and penalized likelihood. Statistics in Medicine, 11: 1305-1319. DOI: 10.1002/sim.4780111005

Compston, J.E., Flahive, J., Hosmer, D.W., Watts, N.B., Siris, E.S., Silverman, S., Saag, K.G., Roux, C., Rossini, M., Pfeilschifter, J., Nieves, J.W., Netelenbos, J.C., March, L., LaCroix, A.Z., Hooven, F.H., Greenspan, S.L., Gehlbach, S.H., Diez-Perez, A., Cooper, C., Chapurlat, R.D., Boonen, S., Anderson, F.A., Adami, S., Adachi, J.D. (2014): Relationship of weight, height, and body mass index with fracture risk at different sites in postmenopausal women. Journal of Bone and Mineral Research, 29(2): 487-493. DOI: 10.1002/jbmr.2051

Cosman, F., De Beur, S.J., LeBoff, M.S., Lewiecki, E.M., Tanner, B., Randall, S., Lindsay, R. (2014): Clinician's guide to prevention and treatment of osteoporosis. Osteoporosis International, 25(10): 2359-2381. DOI: 10.1007/s00198-014-2794-2

Cummings, S.R., Melton, L.J. (2002): Epidemiology and outcomes of osteoporotic fractures. Lancet, 359(9319): 1761-1767. DOI: 10.1016/S0140-6736(02)08657-9

Drinkwater, D.T., Ross, W.D. (1980): Anthropometric fractionation of body mass. Kinanthropometry, II(9): 178-189. 
Gluer, C-G. (1997): International Quantitative Ultrasound Consensus Group (1997) Quantitative ultrasound techniques for the assessment of osteoporosis: expert agreement on current status. Journal of Bone and Mineral Research, 12: 1280-1288. DOI: 10.1359/jbmr.1997.12.8.1280

Hernlund, E., Svedbom, A., Ivergard, M., Compston, J, Cooper, C., Stenmark, J:, McCloskey, E.V., Jönsson, B., Kanis, J.A. (2013): Osteoporosis in the European Union: Medical Management, Epidemiology and Economic Burden. Archives of Osteoporosis, 8: 136. DOI: 10.1007/s11657-013-0136-1

Johnell, O., Kanis, J.A. (2006): An estimate of the worldwide prevalence and disability associated with osteoporotic fractures. Osteoporosis International, 17(12): 1726-1733. DOI: 10.1007/s00198-006-0172-4

Kanis, J., Melton, L., Christiansen, C., Khaltaev, N. (1994): Diagnosis of osteoporosis. Journal of Bone and Mineral Research, 9: 1137-1141. DOI: 10.1002/jbmr.5650090802

Lane, N.E. (2006): Epidemiology, etiology, and diagnosis of osteoporosis. American Journal of Obstetrics and Gynecology, 194(2): S3-S11. DOI: 10.1016/j.ajog.2005.08.047

Njeh, C.F., Boivin, C.M., Langton, C.M. (1997): The role of ultrasound in the assessment of osteoporosis: A review. Osteoporosis International, 7(1): 7-22. DOI: 10.1007/BF01623454

Roux, C., Roberjot, V., Porcher, R., Kolta, S., Dougados, M., Laugier, P. (2001): Ultrasonic backscatter and transmission parameters at the os calcis in postmenopausal osteoporosis. Journal of Bone and Mineral Research, 16(7): 1353-1362. DOI: 10.1359/jbmr.2001.16.7.1353

Svedbom, A., Hernlund, E., Ivergard, M., Compston, J., Cooper, C., Stenmark, J., McCloskey, E.V., Jonsson, B., Kanis, J.A. (2013): Osteoporosis in the European Union. Archives of Osteoporosis, 8: 137-138. DOI: $10.1007 / \mathrm{s} 11657-013-0137-0$

Truscott, J.G. (1997): Reference data for ultrasonic bone measurement: variation with age in 2087 Caucasian women aged 16-93 years. British Journal of Radiology, 70: 1010-1016. DOI: 10.1259/bjr.70.838.9404204

Weaver, C., Gordon, C., Janz, K., Kalkwarf, H., Lappe, J., Lewis, R., M., Wallace, T., Zemel, B. (2016): National Osteoporosis Foundation's statement on peak bone mass development. Osteoporosis International, 27(4): 1281-1386. DOI: 10.1007/s00198-015-3440-3

World Health Organization Study Group (1994): Assessment of fracture risk and its application to screening for postmenopausal osteoporosis. Report of a WHO Study Group. World Health Organization, Technical Report Series, 843: 1-129.

World Health Organization (2003) Prevention and management of osteoporosis. Report of the WHO scientific group (No. 921). Diamond Pocket Books (P) Ltd, London.

Zsákai, A., Mascie-Taylor, N., Bodzsár, É.B. (2015): Relationship between some indicators of reproductive history, body fatness and the menopausal transition in Hungarian women. Journal of Physiological Anthropology, 34(1): 35-43. DOI: 10.1186/s40101-015-0076-0

Zsákai, A., Karkus, Z., Utczás, K., Biri, B., Sievert, L.L., Bodzsár, É.B. (2016): Body fatness and endogenous sex hormones in the menopausal transition. Maturitas, 87: 18-26. DOI: 10.1016/j.maturitas.2016.02.006

Levelezési cím: Mailing address:
Zsákai Annamária

Eötvös Loránd Tudományegyetem

Embertani Tanszék

Pázmány Péter sétány 1/c.

H-1117 Budapest

Hungary

zsakaia@elte.hu 
Függelék - 2. táblázat. Az ultrahangos csontszerkezeti mutatók (DTU-one müszerre) és az abszolút csonttömeg referencia-értékei 25-90 éves magyar nőknél.

Appendix - Táblázat 2. The refernce values of QUS parameters (DTU-one device) and absolute bone mass in Hungarian women aged between 25 and 90 years.

\begin{tabular}{|c|c|c|c|c|c|c|c|c|c|}
\hline \multirow{2}{*}{$\begin{array}{l}\text { Életkor (év) } \\
\text { Age (years) }\end{array}$} & \multicolumn{2}{|l|}{ Átlag } & \multicolumn{7}{|c|}{ Centilisek - Centiles } \\
\hline & Mean & SD & P3 & P10 & P25 & $\mathrm{P} 50$ & P75 & P90 & P97 \\
\hline & \multicolumn{9}{|c|}{ BUA $(\mathrm{dB} / \mathrm{MHz})$} \\
\hline 25 & 54,98 & 13,88 & 44,9 & 48,3 & 51,4 & 54,8 & 57,9 & 60,5 & 63,1 \\
\hline 30 & 53,72 & 15,57 & 42,6 & 46,4 & 49,9 & 53,6 & 57,1 & 60,0 & 62,8 \\
\hline 35 & 51,10 & 15,09 & 39,8 & 44,0 & 48,0 & 52,1 & 56,0 & 59,4 & 62,5 \\
\hline 40 & 49,80 & 13,27 & 37,1 & 41,8 & 46,1 & 50,7 & 55,0 & 58,6 & 62,1 \\
\hline 45 & 48,80 & 15,21 & 34,6 & 39,5 & 44,2 & 49,1 & 53,8 & 57,8 & 61,6 \\
\hline 50 & 47,36 & 13,17 & 32,1 & 37,3 & 42,3 & 47,5 & 52,5 & 56,8 & 60,9 \\
\hline 55 & 44,21 & 13,76 & 29,8 & 35,1 & 40,2 & 45,7 & 51,0 & 55,6 & 60,0 \\
\hline 60 & 42,64 & 14,23 & 27,5 & 32,9 & 38,2 & 43,8 & 49,4 & 54,2 & 58,9 \\
\hline 65 & 40,33 & 15,41 & 25,5 & 30,8 & 36,1 & 41,9 & 47,6 & 52,7 & 57,7 \\
\hline 70 & 38,33 & 15,37 & 23,5 & 28,7 & 34,0 & 39,9 & 45,8 & 51,1 & 56,4 \\
\hline 75 & 37,46 & 13,34 & 21,8 & 26,7 & 31,9 & 37,8 & 43,8 & 49,4 & 54,9 \\
\hline 80 & 35,63 & 14,48 & 20,1 & 24,8 & 29,8 & 35,7 & 41,8 & 47,6 & 53,4 \\
\hline 85 & 33,56 & 16,02 & 18,6 & 23,0 & 27,8 & 33,6 & 39,8 & 45,7 & 51,8 \\
\hline \multirow[t]{2}{*}{90} & 31,09 & 17,14 & 17,1 & 21,2 & 25,8 & 31,5 & 37,7 & 43,8 & 50,2 \\
\hline & \multicolumn{9}{|c|}{ SOS (m/s) } \\
\hline 25 & 1555,8 & 39,0 & 1536 & 1542 & 1548 & 1554 & 1561 & 1567 & 1572 \\
\hline 30 & 1554,8 & 41,6 & 1536 & 1541 & 1547 & 1554 & 1560 & 1566 & 1572 \\
\hline 35 & 1553,3 & 39,9 & 1535 & 1541 & 1547 & 1553 & 1560 & 1566 & 1572 \\
\hline 40 & 1552,3 & 40,5 & 1534 & 1540 & 1546 & 1552 & 1559 & 1565 & 1571 \\
\hline 45 & 1550,9 & 43,9 & 1533 & 1539 & 1545 & 1551 & 1558 & 1564 & 1570 \\
\hline 50 & 1548,5 & 40,3 & 1531 & 1537 & 1543 & 1549 & 1556 & 1562 & 1568 \\
\hline 55 & 1546,1 & 34,4 & 1529 & 1534 & 1540 & 1547 & 1553 & 1559 & 1565 \\
\hline 60 & 1541,8 & 31,3 & 1526 & 1531 & 1537 & 1544 & 1550 & 1556 & 1562 \\
\hline 65 & 1538,6 & 36,2 & 1523 & 1529 & 1534 & 1541 & 1547 & 1554 & 1560 \\
\hline 70 & 1536,3 & 30,7 & 1522 & 1527 & 1532 & 1538 & 1545 & 1551 & 1557 \\
\hline 75 & 1534,0 & 31,6 & 1520 & 1525 & 1530 & 1536 & 1543 & 1549 & 1555 \\
\hline 80 & 1531,6 & 39,2 & 1519 & 1524 & 1528 & 1534 & 1541 & 1547 & 1553 \\
\hline 85 & 1530,6 & 46,1 & 1518 & 1523 & 1527 & 1533 & 1539 & 1545 & 1552 \\
\hline \multirow[t]{2}{*}{90} & 1529,9 & 41,6 & 1518 & 1522 & 1526 & 1532 & 1538 & 1544 & 1550 \\
\hline & \multicolumn{9}{|c|}{ Abszolút csonttömeg - Absolute bone mass (kg) } \\
\hline 25 & 10,06 & 1,26 & 8,1 & 8,6 & 9,2 & 10,0 & 10,9 & 11,8 & 12,9 \\
\hline 30 & 10,29 & 1,48 & 8,2 & 8,7 & 9,3 & 10,1 & 11,1 & 12,1 & 13,3 \\
\hline 35 & 10,49 & 1,40 & 8,3 & 8,8 & 9,5 & 10,3 & 11,3 & 12,3 & 13,6 \\
\hline 40 & 10,65 & 1,71 & 8,3 & 8,9 & 9,6 & 10,5 & 11,5 & 12,6 & 13,9 \\
\hline 45 & 10,74 & 1,51 & 8,3 & 9,0 & 9,7 & 10,6 & 11,7 & 12,8 & 14,1 \\
\hline 50 & 10,80 & 1,75 & 8,3 & 9,0 & 9,7 & 10,7 & 11,8 & 13,0 & 14,3 \\
\hline 55 & 10,80 & 1,58 & 8,3 & 9,0 & 9,8 & 10,7 & 11,9 & 13,1 & 14,4 \\
\hline 60 & 10,72 & 1,79 & 8,2 & 8,9 & 9,7 & 10,8 & 11,9 & 13,1 & 14,4 \\
\hline 65 & 10,63 & 1,68 & 8,1 & 8,9 & 9,7 & 10,7 & 11,9 & 13,1 & 14,4 \\
\hline 70 & 10,51 & 1,85 & 8,0 & 8,7 & 9,6 & 10,6 & 11,8 & 13,0 & 14,2 \\
\hline 75 & 10,39 & 1,89 & 7,8 & 8,6 & 9,4 & 10,5 & 11,6 & 12,7 & 14,0 \\
\hline 80 & 10,23 & 1,51 & 7,7 & 8,4 & 9,3 & 10,3 & 11,4 & 12,4 & 13,6 \\
\hline 85 & 10,06 & 1,49 & 7,5 & 8,2 & 9,0 & 10,0 & 11,1 & 12,1 & 13,1 \\
\hline 90 & 9,82 & 1,36 & 7,3 & 8,0 & 8,8 & 9,7 & 10,7 & 11,7 & 12,7 \\
\hline
\end{tabular}

